\title{
Antioxidant Activity of Palmitic Acid and Pinostrobin From Methanol Extract of Syzygium litoralle (Myrtaceae)
}

\author{
Nurul Hidajati*, Tukiran, Dian Arista Setiabudi, \\ Andika Pramudya Wardana \\ Department of Chemistry \\ Faculty of Mathematic and Natural Science \\ Universitas Negeri Surabaya \\ Surabaya, Indonesia \\ Email (Corresponding Author): nurulhidajati@unesa.ac.id
}

\author{
Kuniyoshi Shimizu \\ Department of Forests and Forest Products Sciences, \\ Faculty of Agriculture \\ Kyushu University \\ Fukuoka, Japan
}

\begin{abstract}
This study presents a research of klampok watu plant (Syzygium littorale) including the Myrtaceae family. As far, only a few report about Syzygium littorale in leaves, fruit, stem bark or other parts. The stem bark of plant was extracted with an organic solvent and then fractionated (isolated) using standard chromatographic techniques. The molecular structure of pure isolates was elucidated and identified with spectroscopic evidence and compared to literature data and authentic sample. The dry powder of the stem bark was extracted with methanol and partitioned with chloroform and hexane, respectively. Isolation of the methanol fraction through vacuum liquid chromatography and followed by recrystallization which always monitored by TLC, yielded a pure compound. The identification result of pure compound showed there are palmitic acid and pinostrobin. The finding of the compounds from the plant is for the first time, although it have previously been found in other Syzygium plants, such as $S$. samarangense, $S$. cumini, $S$. polyanthum, $S$. polycephalum, etc. The methanol fraction, the isolated compounds palmitic acid, pinostrobin, and vitamin $\mathrm{C}$ showed antioxidant activity with IC50 value of 44.85; 189.9; 184.88 , and $11.81 \mu \mathrm{g} / \mathrm{mL}$, respectively.
\end{abstract}

Keywords-antioxidant; klampok watu; palmitic acid; pinostrobin; methanol fraction; Syzygium littorale

\section{INTRODUCTION}

Syzygium litorale that is commonly known as klampok watu or klampok alas is belong to Myrtaceae family. $S$. litorale is a rare plant that can grow in areas near the river. This plant grows and spreads in Malang Regency, located at an altitude of $18 \mathrm{~m}$ above sea level and the upper limit of 405 $\mathrm{m}$ asl [1]. The last research reported that Syzygium was wellknown as an antioxidant properties such as $S$. aquem leaf [2], S. cumini leaf [3], S. polyanthum (Wight) Walp Leaf [4], S. aromaticum fruit [5], and $S$. polycephalum [6]. Utilization of klampok watu plants now, only can be used as household appliance for building because it is so durable and strong. Based on literature data, there is just a few information about $S$. litorale with its antioxidant and other bioactivity potentials. Therefore, we are very interested to do an investigation the stem bark of the plant and bioactivity antioxidants. In this time, this study reported the discovery of palmitic acid and pinostrobin for the first time from the methanol fraction of the plant.

\section{EXPERIMENTAL SECTION}

\section{A. Materials}

The plant materials from stem bark of $S$. litorale (c.a. $25 \mathrm{~kg}$ ) was collected from local area in Bojonegoro, East Java, Indonesia on December 2014. The identification of plant was performed by the staff of Herbarium - LIPI, Purwodadi, East Java, Indonesia. The study used vitamin C (Merck), dichloromethane, hexane, chloroform, ethyl acetate, methanol, silica gel VLC (silica gel 60, 0.040-0.063 mm), silica gel GCC (silica gel 60, 0.200-0500 mm or 70-230 mesh ASTM), plat TLC (Kieselgel gel 60 F254), and 2,2-diphenyl-1picrylhydrazyl (DPPH).

\section{B. Equipment and Instrument}

The equipment used were measuring glass, vials, containers, separating funnel, and vacuum rotary evaporator BUCHI Rotavapor R-215 type, Erlenmeyer flask, pippet, Buchner funnel, spatula, Fisher Scientific used to measure melting points. UV-lamp at $254 \mathrm{~nm}$ or $366 \mathrm{~nm}$ to detect the spots on the plat TLC.

Some instruments needed to identify and characterize an isolate included spectrophotometer FTIR-8400S, spectrophotometer UV-1800 (SHIMADZU), and GC-MS spectrometer with specification of MSM-JMS-700. The ${ }^{1} \mathrm{H}$ NMR spectra with a Bruker DRX-600 NMR spectrometer (600 $\mathrm{MHz}, \mathrm{CD} 3 \mathrm{OD})$ instrument and the ${ }^{13} \mathrm{C}$ NMR spectra were obtained with the same instrument at $150 \mathrm{MHz}$ in CD3OD. Chemical shifts are given in $\delta(\mathrm{ppm})$ values relative to those of the solvent signals [CD3OD $(\delta \mathrm{H} 3.30 ; \delta \mathrm{C} 49.0)$ ] on the tetramethylsilane (Sigma) scale. 


\section{RESEARCH PROCEDURE}

\section{A. Preparation Sample}

The stem bark of $S$. litorale (c.a. $25 \mathrm{~kg}$ ) is cleaned and dried under the sun. After dried the sample is milled. The powder produced was weighed and obtained $9.5 \mathrm{~kg}$. The dried powder was extracted with methanol at room temperature for 24 hours by using maceration. The mixture was then filtered and the filtrate produced was concentrated into a viscous extract (967.6 g). Then, the extract was partitioned with methanol and hexane until yielded two layers. The hexanedissolved portion in the top was evaporated to obtain hexane extract $(15.0 \mathrm{~g})$ and the methanol soluble portion at the bottom was a methanol extract. The methanol extract was then partitioned with methanol and chloroform formed two layers as well. The chloroform soluble portion at the bottom was evaporated obtained chloroform extract (107.8) and methanol soluble portion at the top was obtained as methanol fraction (828.6 g).

A total of $20 \mathrm{~g}$ of methanol fraction was partitioned with mixture (hexane and chloroform $=40: 60$ ) to yield two layers. The bottom layer was then evaporated to obtain $12 \mathrm{~g}$, called as the chloroform fraction. This fraction were continued to separate using vacuum column chromatography (VLC) and conducted for two times with respect eluent methanol: dichloromethane: acetic acid and obtained 15 fractions on VLC-1 and 17 fractions on VLC-2.

Based on TLC analysis, the same fractions were combined and produced 4 combined fractions namely A1 (fraction 1), A2 (fraction 2-5), A3 (fraction 6-10), and A4 (fraction 11-15) for VLC-1. The same manner, it was obtained 4 combined fractions to be B1 (fraction 1), B2 (fraction 2-4), B3 (fraction 5-13), and B4 (fraction 14-17) for VLC-2. On the TLC analysis, it was known that fractions A2 (fraction 2-5) and B2 (fraction 2-4) had the same chromatogram profile and then joined them. They were dried to obtain a white crystal with $100.8 \mathrm{mg}$.

On the other hand, fractions A3 (fraction 6-10) and B3 (fraction 5-13) were combined and dried to obtain white crystals with $120 \mathrm{mg}$. Furthermore, the two white crystal were recrystallized. The crystals were subjected to measure melting point and then performed to identify the molecular structures with UV-Vis, FTIR, GC-MS and NMR spectroscopic evidences.

\section{B. Antioxidant Activity}

DPPH free radicals are stable free radicals. To assess the ability of scavenging 2,2-diphenyl-1-picrylhydrazyl (DPPH), each test sample (methanol fraction, isolated compounds, and standard antioxidants (vitamin C). Dilution series of samples prepared in methanol to a concentration obtained 10, 25, 50, 75, and $100 \mathrm{mg} / \mathrm{mL}$ Reagent DPPH $(0.004 \%$, w/w) was added to a final concentration of $3 \mathrm{~mL}$ mixture was shaken vigorously and incubated in the dark for 30 minutes and the absorbance was measured at $516 \mathrm{~nm}$. Activities scavenging DPPH extract is calculated by using the formula :

$$
\mathrm{I} \%=\left[\left(\mathrm{A}_{\text {blank }}-\mathrm{A}_{\text {sample }}\right) / \mathrm{A}_{\text {blank }}\right] \times 100
$$

where absorbance value of the control was used as $A_{\text {blank }}$ and absorbance value of the test samples was used as $A_{\text {sample }}$ [7] Percentage radical scavenging ability was plotted against the corresponding antioxidant substance concentration. The results were analyzed as $\mathrm{IC}_{50}$ values and were calculated by linear regression analysis of tests condusted in triplicated. The equation for the line is used to obtain the $\mathrm{IC}_{50}$ value. The $\mathrm{IC}_{50}$ value is defined as the concentration of the test sample required to scavenge $50 \% \mathrm{DPPH}$ free radicals. A lower $\mathrm{IC}_{50}$ value indicates greater activity $\mathrm{IC}_{50}<50 \mu \mathrm{g} / \mathrm{mL}$ is very active; $50 \mu \mathrm{g} / \mathrm{mL}<\mathrm{IC}_{50}<100 \mu \mathrm{g} / \mathrm{mL}$ is active; $100 \mu \mathrm{g} / \mathrm{mL}<\mathrm{IC}_{50}<$ $200 \mu \mathrm{g} / \mathrm{mL}$ is moderately active; and $\mathrm{IC}_{50}>200 \mu \mathrm{g} / \mathrm{mL}$ is not active [8].

\section{RESULTS AND DISCUSSION}

\section{A. Structure Determination of The Isolated Compound}

The first isolated compound 1 was obtained as a white crystal $(27 \mathrm{mg})$ with $\mathrm{mp} .61-63^{\circ} \mathrm{C}$. The UV-Vis $(\mathrm{MeOH}$, $\lambda \max )$ spectrum of isolated compound 1 showed maximum absorption at $204 \mathrm{~nm}$ indicating a group of $-\mathrm{COOH}$. The IR spectra of the isolated compound 1 possessing an absorption at 3300 and 1701 indicated the presence of $-\mathrm{OH}$ and $\mathrm{C}=\mathrm{O}$ absorbance, respectively (as seen in Figure 1). From the IR spectrum, it can be seen that there is no aromatic and double bonds in the compound 1. In Figure 2, the IR spectrum of palmitic acid (based on literature data) showed sharp absorption bands at $1705 \mathrm{~cm}-1$ showing the presence of $\mathrm{C}=\mathrm{O}$ group. The presence of $\mathrm{O}-\mathrm{H}$ group of carboxylic acid was shown at the band widened about $3343 \mathrm{~cm}-1$. It was seem that the IR spectrum of isolated compound 1 and those of literate data had a few difference. Therefore, there is similarity of absorption band in Figure 1 and 2 and it was confirmed as palmitic acid. This is the first report of palmitic acid from the S. litorale, although it has previously been found in other Syzygium species such as S. polyanthum [9] and S.cumini [10], etc.

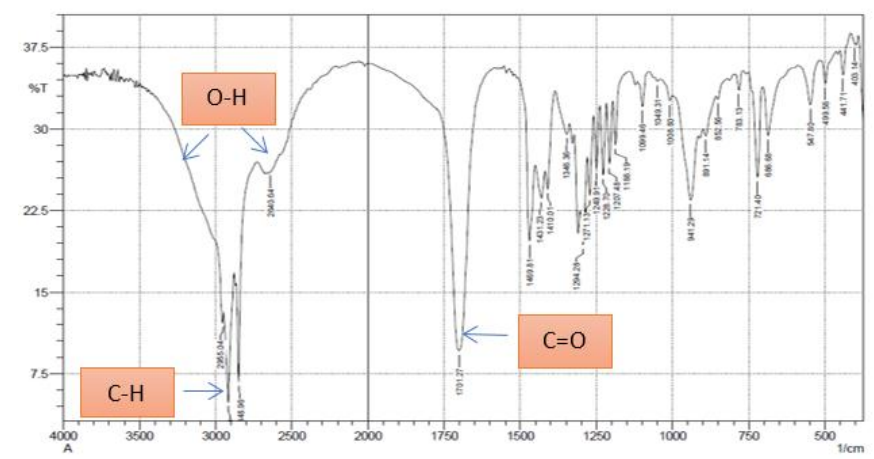

Fig. 1. IR spectral data of isolated compound 1 of S. litorale 


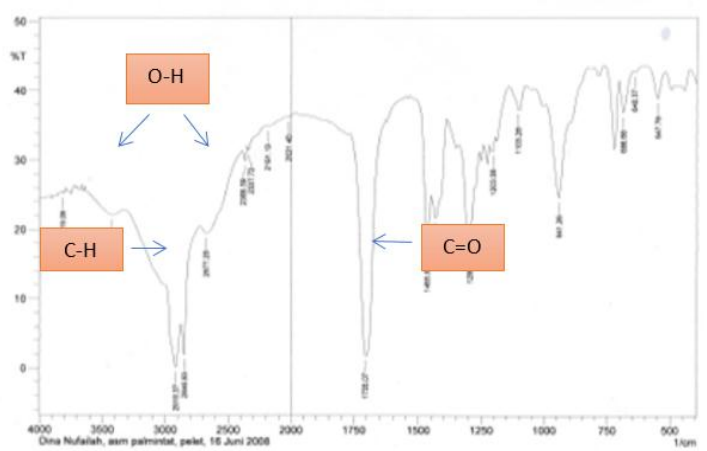

Fig. 2. IR spectral data of palmitic acid

The 1H-NMR spectrum (600 MHz, MeOH-d4, ppm) of isolated compound 1 showed an -OH group at chemical shifts of $11.933 \mathrm{ppm}$ to the integration of $1 \mathrm{H}$, the chemical shift of $\mathrm{H} 3$ lied on 0.855 and those of $\mathrm{H} 2$ lied on 1.237, 1.478, 2.163, 2.176, and 2.188. Based on 1H-NMR analysis, it was shown the presence of DMSO solvent with a chemical shift lied at $2.502 \mathrm{ppm}$.

The 13C-NMR spectrum (150 MHz, MeOH-d4, ppm) of isolated compound 1 showed the presence of carbonyl groups at $\delta \mathrm{C} 174.36$ with integration of $1 \mathrm{C}$ and the presence of $\delta \mathrm{C} 13.85$ indicating $\mathrm{C}$ at $\mathrm{CH}_{3}$ and $\delta \mathrm{C}(22.01,24.42,28.48$, $28.97,31.22,33.59)$ which confirm $-\mathrm{CH}_{2}$ group. The $13 \mathrm{C}-$ NMR analysis showed a strong absorption of solvent that appeared at 39.47. If the $1 \mathrm{H}$ and 13C-NMR spectra of the isolated compound 1 were compared to the palmitic acid (literature data), it may be identical as showed at Table 1 and 2. If compared with literature data, so it had only slight differences. It is necessary to note that this is the first report of the incident in S.litorale, although previously found in other Syzygium species such as S. polyanthum [9] and S. cumini [10].

TABLE I. H-NMR SPECTRAL DATA FOR THE ISOLATED COMPOUND 1 AND PALMITIC ACID

\begin{tabular}{|c|c|c|}
\hline Position & $\begin{array}{c}\text { Isolated Compound 1 } \\
\text { (DMSO) }\end{array}$ & $\begin{array}{c}\text { Palmitic acid } \\
\left(\mathbf{C D C l}_{3}\right)^{*}\end{array}$ \\
\hline $\mathrm{H} 3$ & 0,855 & 0,811 \\
\hline $6,7,8,9,10,11,12,13,14-\mathrm{H} 2$ & 1,237 & 1,256 \\
\hline $15-\mathrm{H} 2$ & 1,478 & 1,631 \\
\hline $2,3,4,5-\mathrm{H} 2$ & 2,$163 ; 2,176 ; 2,188$ & 2,347 \\
\hline $\mathrm{OH}$ & 11,933 & - \\
\hline
\end{tabular}

* Biological Magnetic Resonance Data Bank [11]

TABLE II. C-NMR SPECTRAL DATA FOR THE ISOLATED COMPOUND 1 AND PALMITIC ACID

\begin{tabular}{|c|c|c|c|}
\hline Groups & $\begin{array}{c}\text { Isolated Compound } \\
\text { 1 (DMSO) }\end{array}$ & $\begin{array}{c}\text { Palmitic acid 1 } \\
\left(\mathbf{C D C l}_{\mathbf{3}}\right)^{*}\end{array}$ & $\begin{array}{c}\text { Palmitic acid 2 } \\
\left(\mathbf{C D C l}_{\mathbf{3}}\right)^{* *}\end{array}$ \\
\hline$-\mathrm{CH}_{3}$ & 13.85 & 14.14 & - \\
\hline$-\mathrm{CH}_{2-}$ & 22.01 & 22.27 & - \\
\hline$-\mathrm{CH}_{2-}$ & 24.42 & - & 24.80 \\
\hline$-\mathrm{CH}_{2-}$ & $28.48-28.97$ & $28.95-29.81$ & $29.21-29.81$ \\
\hline$-\mathrm{CH}_{2-}$ & 31.22 & 31.95 & 32.05 \\
\hline$-\mathrm{CH}_{2-}$ & 33.59 & - & 34.23 \\
\hline$-\mathrm{C}=\mathrm{O}$ & 174.36 & - & 180.58 \\
\hline
\end{tabular}

* Biological Magnetic Resonance Data Bank [11]

** Xing-Yu Li [12]
By using GC-MS spectrometer with specification of MSM-JMS-700, the result of GC-MS analysis of the isolated compound 1 was obtained $\mathrm{m} / \mathrm{z} 257$ corresponding to the mass amount of palmitic acid namely 256. Based on these data, it can be concluded that the isolated compound 1 is palmitic acid with molecular formula of $\mathrm{C}_{16} \mathrm{H}_{32} \mathrm{O}_{2}$.

In current, the UV-Vis $(\mathrm{MeOH}, \lambda \max )$ spectrum of isolated compound 2 showed maximum absorption at 287.70 $\mathrm{nm}$ and $212.40 \mathrm{~nm}$ indicating a pinostrobin. The IR spectral analysis of isolated compound 2 showed the maximum absorbance of $\mathrm{C}=\mathrm{C}$ aromatic at $1579.75, \mathrm{C}=\mathrm{O}$ carbonyl at 1643.42, C-O ester or ether at $1157.33, \mathrm{C}-\mathrm{O}$ ether at 1301.99 and $1383.01 \mathrm{~cm}-1$. In Figure 4, the result of the pinostrobin irradiation was obtained by $\mathrm{C}=\mathrm{C}$ aromatic $1571.66, \mathrm{C}=\mathrm{C}$ carbonyl at $1639.37, \mathrm{C}-\mathrm{O}$ ester at 1153.35 and 1299.93 and $\mathrm{C}$ $\mathrm{O}$ ether $1377.93 \mathrm{~cm}-1$. From these results, it can be seen that they have little differences. Therefore, it was confirmed as 5hydroxy-7-methoxyflavanon (pinostrobin). This is the first report from the $S$. litorale although it has previously been found in other Syzygium species such as S. samarangense [13].

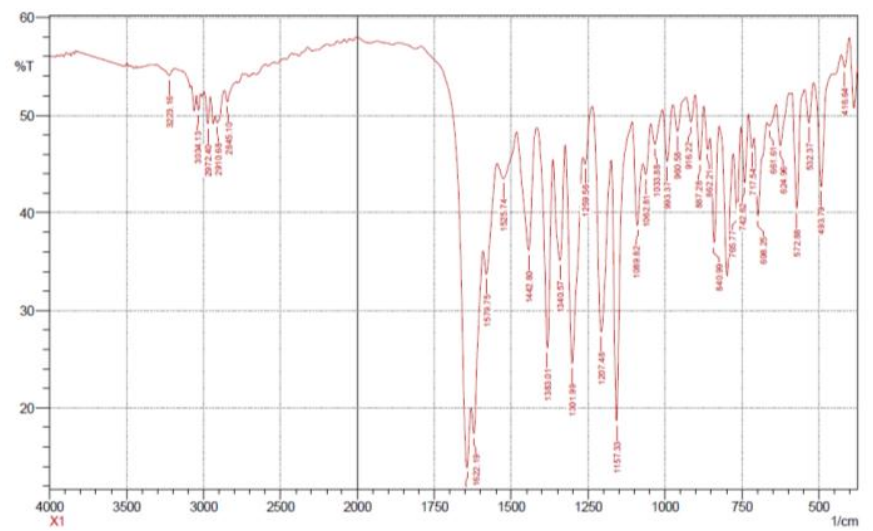

Fig. 3. IR spectral data of isolated compound 2 of S. litorale

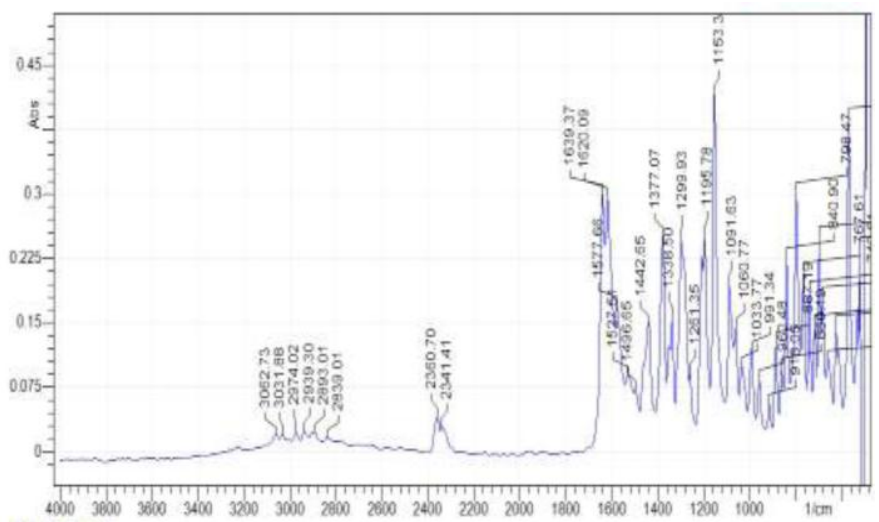

Fig. 4. IR spectral data of pinostrobin

Based on GC-MS analysis, it was obtained $\mathrm{m} / \mathrm{z} 270$ which are in accordance with pinostrobin. The 13C-NMR spectrum (150 MHz, DMSO, ppm) of isolated compound 2 showed one signal for methine group at $\delta \mathrm{C} 78.46(\mathrm{C}-2)$, one aliphatic carbon at $\delta \mathrm{C} 42.04(\mathrm{C}-3)$, one carbon carbonyl at $\delta \mathrm{C}$ 
196.45 (C-4), three oxyaryl carbon at $\delta \mathrm{C} 163.11$ (C-5), 167.39 (C-7), and 162.56 (C-9). Additionally, the 13C-NMR also displayed a methoxy group at $\delta \mathrm{C} 55.83$ (7-OMe) and nine aromatic carbon at $\delta \mathrm{C} 94.68(\mathrm{C}-6), 93.80(\mathrm{C}-8), 102.55(\mathrm{C}$ 10), 138.44 (C-1'), 128.45 (C-2' and C-6'), 128.51 (C-3' and C-5') and 126.55 (C-4). In the 1H-NMR spectrum $(600 \mathrm{MHz}$, DMSO, ppm) of the isolated compound 2 concluded that one oxyalkyl proton signal at $\delta \mathrm{H} 5.64(1 \mathrm{H}, \mathrm{H}-2)$, aliphatic proton at $\delta \mathrm{H} 2.84(1 \mathrm{H}, \mathrm{H}-3 \mathrm{a})$ and $\delta \mathrm{H} 3.29(1 \mathrm{H}, \mathrm{H}-3 \mathrm{~b})$, one of metacoupled aromatic protons at $\delta \mathrm{H} 6.10(1 \mathrm{H}, \mathrm{H}-6)$ and $\delta \mathrm{H} 6.15$ $(1 \mathrm{H}, \mathrm{H}-8)$, monosubstituted phenyl ring $\delta \mathrm{H} 7.43(2 \mathrm{H}, \mathrm{H}-2$ ' and $\left.\mathrm{H}_{-} 6^{\prime}\right), 7.40$ (2H, H-3' and H-5') and 7.52 (1H, H-4'). Additionally, the 1H-NMR also displayed a methoxy group at $\delta \mathrm{H} 3.79(3 \mathrm{H}, 7-\mathrm{OMe})$ and hydroxyl proton at $\delta \mathrm{H} 12.09$. When, 1H-NMR and 13C-NMR spectra of isolated compound 2 were compared with those of 5-hydroxy-7-methoxyflavanone (pinostrobin) as reported in literature data $[14 ; 15]$, it could be identical as shown in Table 3.

TABLE III. H-NMR AND C-NMR SPECTRAL DATA FOR THE ISOLATED COMPOUND 2 AND PINOSTROBIN

\begin{tabular}{|c|c|c|c|c|c|c|}
\hline \multirow{2}{*}{ Position } & \multicolumn{2}{|c|}{$\begin{array}{c}\text { Isolated } \\
\text { Compound } \\
\text { (DMSO) }\end{array}$} & \multicolumn{2}{c|}{$\begin{array}{c}\text { Pinostrobin } \\
\text { (DMSO)* }\end{array}$} & \multicolumn{2}{c|}{$\begin{array}{c}\text { Pinostrobin } \\
\left(\mathbf{C D C l}_{3}\right)^{* *}\end{array}$} \\
\cline { 2 - 7 } & $\begin{array}{c}\delta \mathrm{C} \\
(150 \\
\mathrm{MHz})\end{array}$ & $\begin{array}{c}\delta \mathrm{H} \\
(600 \\
\mathrm{MHz})\end{array}$ & $\begin{array}{c}\delta \mathrm{C} \\
(300 \\
\mathrm{MHz})\end{array}$ & $\begin{array}{c}\delta \mathrm{H} \\
(300 \\
\mathrm{MHz})\end{array}$ & $\begin{array}{c}\delta \mathrm{C} \\
(125 \\
\mathrm{MHz})\end{array}$ & $\begin{array}{c}\delta \mathrm{H} \\
(500 \\
\mathrm{MHz})\end{array}$ \\
\hline 2 & 78,46 & 5,64 & 79,44 & 5,44 & 77,45 & 5,43 \\
\hline 3 & 42,04 & 3,29 & 43,03 & 3,48 & 43,50 & 3,08 \\
\hline 4 & 196,45 & - & 196,60 & - & 195,93 & - \\
\hline 5 & 163,11 & - & 164,10 & - & 164,30 & - \\
\hline 6 & 94,68 & 6,10 & 94,80 & 6,10 & 95,30 & 6,04 \\
\hline 7 & 167,39 & - & 168,36 & - & 168,30 & - \\
\hline 8 & 93,80 & 6,15 & 95,66 & 6,15 & 94,43 & 6,06 \\
\hline 9 & 162,56 & - & 163,52 & - & 163,14 & - \\
\hline 10 & 102,55 & - & 103,52 & - & 103,30 & - \\
\hline 1 & 138,44 & - & 139,41 & - & 138,54 & - \\
\hline $2 ' / 6 '$ & 128,45 & 7,43 & 129,49 & 7,55 & 126,30 & 7,43 \\
\hline $3 ' / 5 '$ & 128,51 & 7,40 & 127,51 & 7,43 & 129 & 7,42 \\
\hline $4{ }^{\prime}$ & 126,55 & 7,52 & 129,43 & 7,43 & 126,30 & 7,43 \\
\hline $7 \mathrm{OMe}$ & 55,83 & 3,79 & 56,57 & 3,81 & 55,85 & 3,81 \\
\hline $5-\mathrm{OH}$ & - & 12,09 & - & 12,10 & - & 12,03 \\
\hline
\end{tabular}

*Pinostrobin compared was isolated Polygonum lapathifolium L. ssp. nodosum (Pers.) Dans [14]

**Pinostrobin compared was isolated Kaempferia rotunda [15]

\section{B. Free Radical-Scavenging Assay}

At this article, the test samples used (methanol fraction, isolated compounds 1 and 2, and Vitamin C) was evaluated for DPPH radical scavenging activity. The value of IC50 antioxidants can be defined as the concentration of test samples required to scavenge $50 \%$ free radical DPPH in a 30 minute period. IC50 values of the test samples were determined to be $44.85,189.9,184.88$ and $11.81 \mu \mathrm{g} / \mathrm{mL}$, respectively. It can be stated that the isolated compound 1 and 2 exhibited a lower hydrogen removal capacity (IC50 $189.9 \mu \mathrm{g} / \mathrm{mL}$ ) and (IC50 $184.88 \mu \mathrm{g} / \mathrm{mL}$ ) than the methanol fraction (IC50 $44.85 \mu \mathrm{g} / \mathrm{mL}$ ) and vitamin C (IC50 $11.81 \mathrm{mg} / \mathrm{mL}$ ) showed more effective hydrogen capacity than the methanol fraction. The antioxidant effects on DPPH are considered because of their hydrogen contributing ability and can function as free radical inhibitors.

The graph showed the percentage of inhibition of methanol fraction, isolated compound (1 and 2) and vitamin $\mathrm{C}$ as shown in Figure 5. It observed that the sample regression equations tested for methanol fraction, isolated compound 1 and 2, vitamin $\mathrm{C}$ were obtained to be $\mathrm{y}=0.2734 \mathrm{x}+37.738\left(\mathrm{R}^{2}\right.$ $=0.9932), \mathrm{y}=0.262 \mathrm{x}-0.4509\left(\mathrm{R}^{2}=0.9948\right), \mathrm{y}=0.2796 \mathrm{x}-$ $1.693\left(\mathrm{R}^{2}=0.9959\right)$ and $\mathrm{y}=0.2244 \mathrm{x}+47.349\left(\mathrm{R}^{2}=0.9917\right)$, respectively. Headings, or heads, are organizational devices that guide the reader through your paper. There are two types: component heads and text heads.

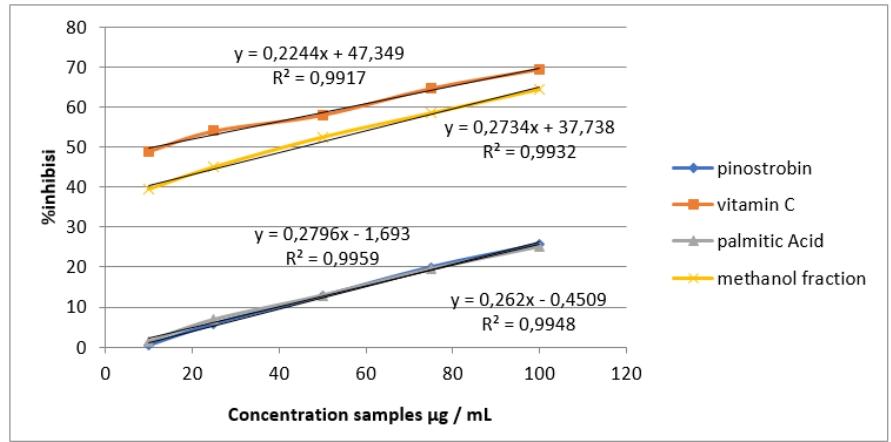

Fig. 5. Comparison of percentage inhibition of isolated compound (palmitic acid and pinostrobin), methanol fraction and vitamin $\mathrm{C}$

\section{CONCLUSION}

It had been isolated two compounds from the methanol fraction of $S$. litorale stem bark and also identified successfully as palmitic acid and pinostrobin. These compound were found for the first time from $S$. litorale. Antioxidant activity of these compounds (isolated compound $\mathbf{1}$ with IC50 value $189.9 \mathrm{mg} / \mathrm{mL}$ and isolated compound 2 with IC50 value $184.88 \mathrm{mg} / \mathrm{mL}$ ) and fraction methanol (IC50 value $44.85 \mathrm{mg} / \mathrm{mL}$ ) were less active than those of vitamin $\mathrm{C}$ as positive control with IC50 value of $11.81 \mathrm{mg} / \mathrm{mL}$.

\section{REFERENCES}

[1] D. Mudiana, "Diversity and Study of Habitat Klampok (Syzygium) in Malang, East Java", Unpublished LIPI Research Incentives and Research Incentives Report. Purwodadi: UPT Center for Conservation of Botanical Garden Purwodadi, LIPI, 2010

[2] H. Osman, A. R. Afidah, M. I. Norhafizah and M. B. Nornaemah, "Antioxidant Activity and Phenolic Content of Paederia foetida and Syzygium aqueum”, Molecules. 14, 970-978, 2009

[3] Z. P. Ruan, L. Z. Liang, and M. L. Yi, "Evaluation of The Antioxidant Activity of Syzygium cumini Leaves", Molecules, 13, 2545-2556, 2008

[4] L. W. Har, and I. S. Ismail, "Antioxidant Activity, Total Phenolics and Total Flavonoid of Syzygium polyanthum (Wight) Walp Leaves”, Int. J. Med. Arom. Plants, 2(2), 219-228, 2009

[5] A. Wojdylo, J. Oszmianski, and R. Czemerys, "Antioxidant Activity and Phenolic Compounds in 32 Selected Herbs", Journal of Food Chemistry. 105: 940-949, 2007 
[6] Tukiran, A. P. Wardana, N. Hidajati, and K. Shimizu, "An Ellagic Acid Derivative and Its Antioxidant Activity of Stem Bark Extracts of Syzygium polycephalum Miq. (Myrtaceae). Indonesian Journal of Chemistry. 18(1), 26-34, 2018

[7] R. A. Khan, M. R. Khan, S. Sahreen, and M. Ahmed, M. "Evaluation of Phenolic Contents and Antioxidant Activity of Various Solvent Extracts of Sonchusasper (L.) Hill”, Chemistry Central Journal, 6(12), $1-7,2012$

[8] K. A. Reynertson, "Phytochemical Analysis Of Bioactive Constituents from Edible Myrtaceae Fruits". A Dissertation Submitted to the Graduate Faculty in Biology in partial fulfillment of the requirements for the Degree of Doctor of Philosophy, The City University of New York. Science, 4(3-8). 2007

[9] A. Fitriani, "Antifungi Activity Ethanol Extract Leaf Salam (Syzygium polyanthum (Wight) Walp.) Against Candida albicans Mushroom Growth in vitro", Biosphere Journal, 29(2), 2012

[10] P. Sari, "Potential Antosianin Duwet Fruit (Syzygium cumini) Become Natural Food Coloring Which Have Antioxidation Ability", IPB: Thesis, 2011
[11] Biological Magnetic Resonance Data Bank, http://www.bmrb.wisc.edu/search/instant.php?term=palmitic+acid, access on July, $5^{\text {th }} 2018$

[12] Xing-Yu Li, Ming-Chen Fu, Rui Shang, and Y. J. Fu, "Conversion of Biomass-derived Fatty Acids and Derivatives into Hydrocarbons Using a Metal-Free Hydrodeoxygenation Process", 17(5), 2015

[13] E. C. Amo, I. M. Villasenor, M. N. Ghayur, A. H. Gilani and M. I. Choudhary, "Spasmolytic Flavonoids from Syzygium Samarangense (Blume) Merr. \& L.M. Perry”, Zeitschrift Naturforschung, 60 (1-2), 67 71,2005

[14] H. D. Smolarza, E. Mendyk, A. Bogucka-Kockaa, and J. Kockic, "Pinostrobin - An Anti-Leukemic Flavonoid from Polygonum lapathifolium L. ssp. nodosum (Pers.) Dans", Z. Naturforsch C, 61(12), (64-68). 2006

[15] S, Atun, R. Arianingrum, E, Sulistyowati, and N. Aznam, "Isolation and Antimutagenic Activity of Some Flavanone Compounds from Kaempferia rotunda", International Journal of Chemical and Analytical, 4(2013), 3-8, 2013 